\title{
Dietary intake of menaquinone-4 may determine hepatic and pancreatic menaquinone-4 in chickens
}

\author{
Merete Askim I*, Anna Haug ${ }^{2}$ and Gaut Gadeholt ${ }^{3}$ \\ 'Department of Technology, Sør-Trøndelag University College; ²Department of Animal and Aquacultural Sciences, \\ Norwegian University of Life Sciences, Aas, Norway; ${ }^{3}$ Department of Clinical pharmacology, Oslo university hospital, \\ Oslo, Norway
}

\section{Abstract}

Objective: The aim of this study was to determine the biological effects of natural dietary intake of vitamin $\mathrm{K}$ as phylloquinone $\left(\mathrm{K}_{1}\right)$ and menaquinone-4 (MK-4) and a control diet also containing menadione $\left(\mathrm{K}_{3}\right)$ on levels of $\mathrm{K}_{1}$ and total MK-4 (menaquinone-4) and menaquinone-4-2,3-epoxide (MK-4O) in liver and pancreas, and on femur bending resistance in a fast-growing animal model.

Design: Chickens were fed four wheat-based diets from day 11 to day 22 after hatching. The diets contained different combinations of fat sources: rapeseed oil, animal rendered fat, soybean oil and hydrogenated soybean oil. Concentration of $\mathrm{K}_{1}$ in the three experimental diets was $120 \mathrm{ng} / \mathrm{g}$ whereas MK-4 levels were 23, 52 and $63 \mathrm{ng} / \mathrm{g}$ respectively. The control diet contained $157 \mathrm{ng} \mathrm{K} / \mathrm{g}, 75 \mathrm{ng} \mathrm{MK}-4 / \mathrm{g}$ and $2.250 \mathrm{ng} \mathrm{K} / \mathrm{g}$.

Results: Growth rates and femur strength confirmed adequate supply of nutrients and vitamin $\mathrm{K}$ in the test groups. There were no significant differences in femur bending resistance among the test groups, but these were higher than the control. $\mathrm{K}_{1}, \mathrm{MK}-4$ and MK-4O were found in liver. In pancreas, mainly MK-4O was found with small amounts of MK-4, but none had content of $\mathrm{K}_{1}$. In the test groups the hepatic levels of MK-4 and MK-4O reflected the dietary intake of MK-4.

Conclusion: The chickens were in good health with good bone resistance without supplements of $\mathrm{K}_{3}$ in the feed, but at least a natural content of $23 \mathrm{ng}$ MK-4/g feed. Liver and pancreas appears to use MK-4 in different ways.

Keywords: Menaquinone-4; diet; liver; pancreas; chicken

I has been shown experimentally that oral absorption of phylloquinone (vitamin $\mathrm{K}_{1} ; \mathrm{K}_{1}$ ) is higher when it is taken as a pharmaceutical preparation than when it is taken as part of a meal in which the vitamin is naturally present (1). Dietary $\mathrm{K}_{1}$ as well as the closely related menaquinone-4 (MK-4) are transported with different lipoproteins in the blood (2). Different tissues have different mechanisms of uptake of vitamin-carrying plasma proteins, resulting in differences in the equilibrium concentrations of $\mathrm{K}_{1}$ and MK-4 $(3,4)$. There is also evidence that MK-4 can be synthesized in tissues from menadione (vitamin $\mathrm{K}_{3} ; \mathrm{K}_{3}$ ), either as such (5), derived from $K_{1}(6-9)$, or by direct substitution (10). In many of these studies the experimental animals were deprived of vitamin $\mathrm{K}$ or given overly high doses of $\mathrm{K}_{1}$.

Chickens have been bred for high utilization of feed and high rates of growth. During the first 3 weeks of life a typical chicken will increase its body mass by a factor of 20. Chickens cannot perform de novo synthesis of vitamin $\mathrm{K}$; hence the tissue levels of vitamin $\mathrm{K}$ measured after the feeding period would in some way have to be related to the dietary intake. Any vitamin K present at the start of experimental feeding would provide only a limited fraction of the total amount present. Liver is the main site of synthesis for vitamin K-dependent coagulation factors and has been shown to possess the apparatus necessary to synthesize MK-4 (5, 7, 9). Pancreas has been reported to have higher values of MK-4 than most other tissues, possibly owing to $\mathrm{K}_{1}$ to-MK-4 conversion $(11,12)$ and possibly related to the secretion of MK-4 in pancreatic juice (13). In chickens, the activity of epoxide reductase per gram tissue has been found to be $10 \%$ of the activity in rats (6), explaining why a high proportion of the vitamin $\mathrm{K}$ material of chickens is present as the 2,3-epoxide. 
The present study was designed to investigate how ordinary dietary doses of vitamin $\mathrm{K}$ would influence tissue accumulation of $\mathrm{K}_{1}$ and MK-4. Care was taken to vary only the dietary concentration of MK-4 together with an adequate and stable concentration of $\mathrm{K}_{1}$, and in an identical feed matrix so as to limit any feedinduced variations in bioavailability. For comparison regarding the adequacy of the feeds a control group receiving the standard chicken feed containing additional $\mathrm{K}_{3}$ was included.

Vitamin K-dependent carboxylation of bone matrix proteins is regarded as important for bone matrix calcification (14). Bone strength was measured to investigate whether our modest variations in vitamin $\mathrm{K}$ content could be detected in this system.

\section{Methods}

\section{Chickens}

Fifty-seven newly hatched male chickens (Samvirke kylling Norway, Ross 308) from the same hatching farm were used in this experiment conducted at The Norwegian University of Life Sciences. Animal treatment and animal facilities all complied with the Guide for the Care and Use of Laboratory Animals (15). The experimental animal research followed internationally recognized guidelines. All animals were cared for according to Norwegian laws and regulations for experiments with live animals (The Animal Protection Act of December 20th, 1974, and the Animal Protection Ordinance Concerning Experiments with Animals of January 15th, 1996).

\section{Experimental design}

The chickens were randomly assigned into one of four dietary 22 day treatments. During the first 10 days each group of 14 to 15 animals were kept in deep littered pens; $75 \mathrm{~cm} \times 150 \mathrm{~cm}$. At day 10 they were weighed and individually placed in wire-floored metabolism cages up until day 22. The chickens were raised in an environmentally controlled room. The room temperature was maintained at $32^{\circ} \mathrm{C}$ from days $0-3$, then gradually reduced by $0.5^{\circ} \mathrm{C}$ per day until day 22 . They were exposed to $23 \mathrm{~h}$ light and $1 \mathrm{~h}$ dark photoperiod days $0-7$, the next 2 weeks they were exposed to $2 \times 4 \mathrm{~h}$ dark; the dark periods were between 17-21 $\mathrm{h}$ and 00-04 $\mathrm{h}$. The chickens had free access to feed and water. Water troughs and wire-floors were cleaned daily, with small possibility of coprophagy. Feed intake and body weight were registered day 11 to day 22 . None of the birds were sick or died during the feeding period.

\section{Sampling}

At day 22 the chickens were weighed, killed by carbon dioxide narcosis and dissected immediately after death. Organs and limbs were packed in aluminum foil, frozen in liquid nitrogen and stored at $-20^{\circ} \mathrm{C}$ before being analyzed.

\section{Vitamin $K$ in diets}

Rapeseed oil was purchased from AFB, Askim, Norway and contained $60 \%$ oleic acid, $20 \%$ linoleic acid and $10 \%$ alpha linolenic acid. Rendered animal fat (RAF) was obtained locally and contained fat from ruminants (about 70\%) and pigs (about 30\%). The composition of RAF was (by weight): $26 \%$ palmitic acid, $18 \%$ stearic acid, 36\% oleic acid and 8\% linoleic acid. Fully hydrogenated soybean oil (HSO), refined to remove $\mathrm{K}_{1}$ and ineffective dihydrophylloquinone together with trans-fatty acids, were purchased from AAK (AarhusKarlshamn) Sweden AB. The level of $\mathrm{K}_{1}$ in HSO was less than $10 \%$ of the original amount in untreated soybean oil. Dihydrophylloquinone was not detected in the oils.

All four feeds were wheat based and composed according to guidelines adjusted to the requirements of chickens (Table 1). The feeds were manufactured at ForTek, Aas, Norway, with a matrix type $2.5 \mathrm{~mm} \times 46 \mathrm{~mm}$ at a rate of $600 \mathrm{~kg} / \mathrm{h}$. They had the same basic composition with regard to protein, carbohydrates, minerals and vitamins except vitamin K. All diets contained lipid in the form of oils and solid fats. The control (CTR) feed group contained vitamin $\mathrm{K}_{1}$ from rapeseed oil and soy bean oil; MK-4 from RAF and added $\mathrm{K}_{3}$. The experimental feeds contained natural levels of $\mathrm{K}_{1}$ and MK-4 from

Table 1. Composition of the experimental feeds including levels of vitamin $\mathrm{K}$

\begin{tabular}{lcccc}
\hline Ingredients & CTR & MIX & RAF & HSO \\
\hline Wheat (\%) & 60 & 60 & 60 & 60 \\
Soybean meal (\%) & 20 & 20 & 20 & 20 \\
Fish meal (\%) & 3 & 3 & 3 & 3 \\
Rapeseed oil (\%) & 5 & 0 & 0 & 0 \\
Animal Rendered fat (\%) & 5 & 4 & 8 & 0 \\
Soybean oil (\%) $_{\text {Hydrogenated soybean oil (\%) }}$ & 0 & 2 & 2 & 2 \\
Mineral mixture $^{\text {a }}$ (\%) & 0 & 4 & 0 & 8 \\
Vitamin mixture $^{\mathrm{a}}$ (\%) & 0.15 & 0.15 & 0.15 & 0.15 \\
MK-4 (ng/g feed) $_{\text {K }_{\text {I }} \text { (ng/g feed) }}$ & 0.08 & 0.08 & 0.08 & 0.08 \\
K $_{3}$ ( ng/g feed) & 75.3 & 62.5 & 51.6 & 22.6 \\
\hline
\end{tabular}

Notes: All feeds contained Monocalcium phosphate 2\%; Ground limestone 1.85\%; $\mathrm{NaCl} 0.25 \%$; DL-Methionine 0.4\%, L-lysine 0.3\%; L-Threonine $0.1 \%$; Choline chloride $0.13 \%$ and $\mathrm{MgO} 6.57 \times 10^{-3} \%$. ${ }^{a} V$ itamin and mineral mixture provided the following per $\mathrm{kg}$ feed: retinyl acetate, $2.7 \mathrm{mg}$; cholecalsiferol, $0.07 \mathrm{mg}$; DL-alpha tocopheryl acetate, $38 \mathrm{mg}$; pyridoxine, $3.4 \mathrm{mg}$; riboflavin, $9 \mathrm{mg}$; Ca-pantothenate, $12.5 \mathrm{mg}$; biotin, $0.19 \mathrm{mg}$; thiamine, $1.9 \mathrm{mg}$; niacin, $37.5 \mathrm{mg}$; cobalamine, $0.02 \mathrm{mg}$; folic acid, $1.5 \mathrm{mg}$; choline chloride, $500 \mathrm{mg}$; manganese, $75 \mathrm{mg}$; zinc, $75 \mathrm{mg}$; iron, $95 \mathrm{mg}$; cupper, $10 \mathrm{mg}$; iodine, $0.6 \mathrm{mg}$; selenium, $0.43 \mathrm{mg}$. 
RAF, fully HSO or a mixture of animal rendered fat and fully HSO (MIX). The experimental diets contained $2 \%$ natural soybean oil to provide a small supplement of $\mathrm{K}_{1}$ (Table 1). $\mathrm{K}_{1}$ content of the control diet was $32 \%$ higher than the experimental feeds. The experimental feeds had MK-4 levels from 20 to $50 \%$ of the $\mathrm{K}_{1}$ level.

\section{Vitamin $K$ analysis}

Vitamin $\mathrm{K}$ in liver, pancreas and feeds were analyzed by HPLC using a $\mathrm{C}-18$ reversed phase column and fluorometric detection after postcolumn electrochemical reduction according to Thijssen et al. (16).

\section{Testing of bone strength}

The right femur was thawed gently and dissected free of muscle. Bending resistance was tested in a TA-XT2 texture analyzer from Stable Micro Systems, Godalming, Surrey, UK (www.stablemicrosystems.com). Probe velocity was at $0.1 \mathrm{~mm} / \mathrm{s}$, and the distance between the supports was $32.5 \mathrm{~mm}$. Load-versus-time curves were generated and analyzed by means of Texture Expert Exceed v2.64 software. Bending resistance was calculated from the initial linear segment of the graphs and expressed as $\mathrm{N} / \mathrm{mm}$.

\section{Statistical analyses}

Statistical calculations (linear regression) on the effect of the four dietary treatments were performed by SPSS 15.0 IBM SPSS, Statistical Analyses Software (http:// www.spss.com/), using comparative means by one-way ANOVA and Bonferroni test for assumption of equal variances.

\section{Results}

\section{Chicken growth}

Weight at day 11 and 22 showed that the chickens in the experimental groups ate slightly more and the RAF and HSO group grew significantly faster than the MIX and CTR groups indicating a satisfactory nutritional status (Table 2).

Total amount of MK-4 eaten by the chicken was significantly different, being highest in the CTR group and lowest in the HSO group, while for $\mathrm{K}_{1}$ no difference between experimental group but significantly higher in the control group (Table 2).

\section{Vitamin $K$ in liver and pancreas}

Pancreas had higher vitamin $K$ concentration than liver (Table 3). In liver, MK-4 was the most abundant vitamer, while in pancreas $\mathrm{MK}-4 \mathrm{O}$ was the main vitamer. $\mathrm{K}_{1}$ was not detected in pancreas (Table 3). The association between the amounts of MK-4 consumed and MK-4 in liver was statistically significant.
Table 2. Information on feed and weight of the chicken from day 11 to day 22

\begin{tabular}{|c|c|c|c|c|}
\hline & CTR & MIX & RAF & $\mathrm{HSO}$ \\
\hline $\begin{array}{l}\mathrm{n}=\text { number of } \\
\text { chickens }\end{array}$ & 15 & 14 & 14 & 14 \\
\hline $\begin{array}{l}\text { Chicken weight } \\
\text { day II (g) }\end{array}$ & $268(18)^{a, c, d}$ & $243(13)^{b, d}$ & $274(16)^{a, c}$ & $256(\mid 3)^{\mathrm{a}, \mathrm{b}, \mathrm{d}}$ \\
\hline $\begin{array}{l}\text { Chicken weight } \\
\text { day } 22(\mathrm{~g})\end{array}$ & $800(84)^{\mathrm{a}}$ & $827(48)^{a}$ & $939(68)^{b}$ & $936(63)^{\mathrm{b}}$ \\
\hline Liver weight (g) & $28(3)^{a, b}$ & $27(3)^{\mathrm{a}}$ & $30(3)^{b}$ & $30(5)^{\mathrm{b}}$ \\
\hline Feed intake $(\mathrm{g})$ & $680(72)^{\mathrm{a}}$ & $70 I(4 I)^{a, b}$ & $746(5 \mathrm{I})^{\mathrm{b}}$ & $766(64)^{\mathrm{b}}$ \\
\hline $\mathrm{K}_{\mathrm{I}}$ intake $(\mu \mathrm{g})$ & $107(11)^{\mathrm{a}}$ & $84(5)^{\mathrm{b}}$ & $90(6)^{b}$ & $92(8)^{\mathrm{b}}$ \\
\hline $\begin{array}{l}\text { MK-4-intake } \\
(\mu \mathrm{g})\end{array}$ & $5 \mathrm{I}(5)^{\mathrm{a}}$ & $44(3)^{\mathrm{b}}$ & $38(3)^{c}$ & $17(I)^{d}$ \\
\hline $\mathrm{K}_{\mathrm{I}}$ intake $(\mu \mathrm{g})$ & 1,530 & & & \\
\hline
\end{tabular}

Notes: Values are means and SD.

${ }^{a-d}$ Means with different letters within the same row are significantly different at the $5 \%$ level.

The concentration of total MK-4 and MK-4O in pancreas as well as in liver is associated with MK-4 consumed.

\section{Bone strength}

The bending resistance of the femur was slightly higher in the experimental groups than in the control group, with no difference between the experimental groups (Table 3).

Table 3. Levels of vitamin $\mathrm{K}$ in liver and pancreas and femur bending resistance

\begin{tabular}{|c|c|c|c|c|}
\hline & CTR & MIX & RAF & $\mathrm{HSO}$ \\
\hline \multicolumn{5}{|l|}{ Liver } \\
\hline$K_{1}(n g / g)$ & $47(I I)^{a}$ & $28(\mathrm{II})^{\mathrm{b}}$ & $35(16)^{a}$ & $26(12)^{b}$ \\
\hline MK-4 (ng/g) & $425(66)^{a}$ & $238(56)^{b}$ & $105(22)^{c}$ & $59(14)^{c}$ \\
\hline MK-4O (ng/g) & $104(29)^{\mathrm{a}}$ & $80(25)^{b}$ & $38(16)^{c}$ & $23(16)^{c}$ \\
\hline MK-4/(MK-4+MK-4O)\% & $75(9)$ & $66(11)$ & $64(14)$ & $63(20)$ \\
\hline \multicolumn{5}{|l|}{ Pancreas } \\
\hline MK-4O (ng/g) & $1,158(617)^{a}$ & $522(35 \mathrm{I})^{\mathrm{b}}$ & $316(186)^{c}$ & $=118(61)^{c}$ \\
\hline MK-4 (ng/g) & $59(86)$ & $32(49)$ & $7(9)$ & II (9) \\
\hline MK-4/(MK-4+MK-4O)\% & $5(13)$ & $6(13)$ & $2(4)$ & $9(9)$ \\
\hline \multicolumn{5}{|l|}{ Femur } \\
\hline $\begin{array}{l}\text { Bending resistance } \\
(\mathrm{N} / \mathrm{mm})\end{array}$ & $85(10)^{a}$ & $96(13)^{b}$ & $98(11)^{b}$ & $102(12)^{b}$ \\
\hline
\end{tabular}

Notes: Values are means and SD.

${ }^{a-d}$ Means with different letters within the same row are significantly different at the $5 \%$ level. 


\section{Discussion}

It has long been known that MK-4 is being synthesized in tissues of animals. Our experimental model seems to suggest that conversion of $\mathrm{K}_{1}$ to MK-4 did not take place in the presence of adequate levels of MK-4 in the feed, not even in the feed group with the lowest level of MK-4 (HSO). In the test groups the hepatic levels of MK-4 and MK-4O reflected the dietary intake of MK-4. Recently, a specific enzyme that converts $\mathrm{K}_{1}$ to $\mathrm{MK}-4$ has been discovered and described (10). The production capacity of this enzyme has not been compared with or distinguished from the menadione prenylation system (5), so published evidence is as yet insufficient for a full quantitative picture of the various sources and pathways of synthesis in normally fed animals. MK-4O was in a different way dependent on the vitamin in the feed. The control group had the highest MK-4O levels in pancreas. This could be related to the supplementary $K_{3}$ given to that group only. Liver and pancreas appears to use MK-4 in different ways; in liver $1 / 3$ of MK-4 is converted to $\mathrm{MK}-4 \mathrm{O}$ while in pancreas almost all is as MK-4O. The content of $\mathrm{K}_{1}$ in liver was higher in the control group. The feed for this group contained more $\mathrm{K}_{1}$ and $\mathrm{K}_{3}$ was added.

\section{Conclusion}

The chickens were in good health with good bone resistance without supplements of $K_{3}$ in the feed but at least a natural content of $23 \mathrm{ng} \mathrm{MK}-4 / \mathrm{g}$ feed. Liver and pancreas appears to use MK-4 in different ways.

\section{Acknowledgements}

The authors wish to thank the University College in Sør-Trøndelag for financial support. We are grateful to the personnel working at the Department of Animal and Aquacultural Sciences for conducting the broiler experiment, and the staff working at the laboratory at the Norwegian University of Life Sciences for helping with preparation and analysis of the samples.

\section{Conflicts of interest and funding}

The author have not received any funding or benefits from industry.

\section{References}

1. Schurgers LJ, Vermeer C. Determination of phylloquinone and menaquinones in food. Effect of food matrix on circulating vitamin K concentrations. Haemostasis 2000; 30: 298-307.

2. Schurgers LJ, Vermeer C. Differential lipoprotein transport pathways of K-vitamins in healthy subjects. Biochim Biophys Acta 2002; 1570: 27-32.
3. Niemeier A, Kassem M, Toedter K, Wendt D, Ruether W, Beisiegel U, et al. Expression of LRP1 by human osteoblasts: a mechanism for the delivery of lipoproteins and vitamin $\mathrm{K}_{1}$ to bone. J Bone Miner Res 2005; 20: 283-93.

4. Suhara Y, Murakami A, Nakagawa K, Mizuguchi Y, Okano T. Comparative uptake, metabolism, and utilization of menaquinone-4 and phylloquinone in human cultured cell lines. Bioorgan Med Chem 2006; 14: 6601-7.

5. Dialameh GH, Yekundi KG, Olson RE. Enzymatic alkylation of menaquinone- 0 to menaquinones by microsomes from chick liver. Biochim Biophys Acta 1970; 223: 332-8.

6. Will BH, Usui Y, Suttie JW. Comparative metabolism and requirement of vitamin K in chicks and rats. J Nutr 1992; 122: 2354-60.

7. Lee FC, Olson RE. Localization of the menaquinone-0 alkylating enzyme in the smooth reticulum of chicken liver microsomes. Biochim Biophys Acta 1984; 799: 166-70.

8. Thijssen HHW, Vervoort LMT, Schurgers LJ, Shearer MJ. Menadione is a metabolite of oral vitamin K. Br J Nutr 2006; 95: 260-6.

9. Okano T, Shimomura Y, Yamane M, Suhara Y, Kamao M, Sugiura M, et al. Conversion of Phylloquinone (Vitamin $\mathrm{K}_{1}$ ) into Menaquinone-4 (Vitamin $\mathrm{K}_{2}$ ) in mice: two possible routes for menaquinone- 4 accumulation in cerebra of mice. J Biol Chem 2008; 283: 11270-9.

10. Nakagawa K, Hirota Y, Sawada N, Yuge N, Watanabe M, Uchino Y, et al. Identification of UBIAD1 as a novel human menaquinone-4 biosynthetic enzyme. Nature 2010; 468: 117-22.

11. Thijssen HHW, Drittij-Reijnders MJ. Vitamin K status in human tissues: tissue-specific accumulation of phylloquinone and menaquinone-4. Br J Nutr 1996; 75: 121-7.

12. Ronden JE, Thijssen HHW, Vermeer C. Tissue distribution of $\mathrm{K}$-vitamers under different nutritional regimens in the rat. Biochim Biophys Acta 1998; 1379: 16-22.

13. Thomas DDH, Krzykowski KJ, Engelke JA, Groblewski GE. Exocrine pancreatic secretion of phospholipid, menaquinone-4, and caveolin-1 in vivo. Biochem Biophys Res Comm 2004; 319: 974-9.

14. Gundberg CM, Nishimoto SK. Vitamin K dependent proteins of bone and cartilage. In: Seibel MJ, Robins SP, Bilezikian JP, eds. Dynamics of bone and cartilage metabolism. New York: Academic Press; 2006, p. 55-70.

15. Dyrevelferdsloven, European Convention for the Protection of Vertebrate Animals used for Experimental and Other Scientific Purposes, CETS No.: 123 1986. http://conventions.coe.int/treaty/ Commun/QueVoulezVous.asp?CL $=$ ENG\&NT $=123$

16. Thijssen HHW, Drittij-Reijnders MJ, Fischer MAJG. Phylloquinone and menaquinone-4 distribution in rats: synthesis rather than uptake determines menaquinone-4 organ concentrations. J Nutr 1996; 126: 537-43.

\author{
*Merete Askim \\ AFT \\ HiST \\ NO-7004, Trondheim \\ Norway \\ Email: merete.askim@gmail.com
}

